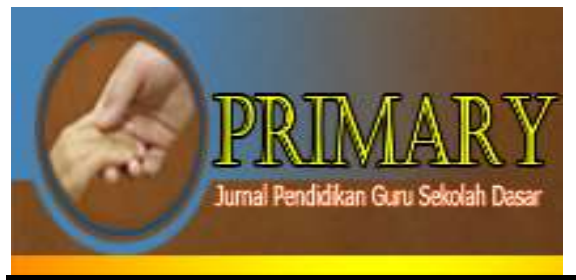

\author{
PRIMARY: JURNAL PENDIDIKAN GURU SEKOLAH DASAR \\ VOLUME 10 NOMOR 6 DESEMBER 2021 \\ ISSN : 2303-1514 | E-ISSN : 2598-5949 \\ DOI : http://dx.doi.org/10.33578/jpfkip.v10i6.8620 \\ https://primary.ejournal.unri.ac.id/index.php/JPFKIP
}

\title{
PERAN KEPALA SEKOLAH DALAM MENINGKATKAN KETERAMPILAN MENGAJAR GURU DI SDN 20 RUPAT
}

\author{
Rosmita
}

SDN 20 Rupat, Bengkalis, Riau, Indonesia rosmitarpt20@gmail.com

\section{THE PRINCIPAL'S ROLE IN IMPROVING TEACHERS' TEACHING SKILLS AT SDN 20 RUPAT}

\begin{tabular}{|c|c|}
\hline ARTICLE HISTORY & ABSTRACT \\
\hline $\begin{array}{l}\text { Submitted: } \\
18 \text { Oktober } 2021 \\
18^{\text {th }} \text { October } 2021\end{array}$ & $\begin{array}{l}\text { Abstract: This research was school action research conducted by the principal using } \\
\text { quantitative descriptive methods. This research explained and described the research results } \\
\text { based on the facts found. This research was conducted at SDN } 20 \text { Rupat. The research subjects } \\
\text { were the teachers who taught at SDN } 20 \text { Rupat. The results of the research found an increase } \\
\text { in teachers' skills in teaching and an increase in teachers' activity in learning after several } \\
\text { actions taken by the principal against the teacher. The following is the data from the analysis } \\
\text { of teachers' teaching skills. The average percentage of teachers' teaching skills was } 79.4 \text {. The } \\
\text { percentage on the indicator of opening and closing lessons was } 75.5 \% \text {. Then, the percentage } \\
\text { on the questioning skill indicator was } 82 \% \text { and on the skill indicator of providing } \\
\text { reinforcement to the students was } 80.5 \% \text {. Next, the percentage on the indicator of skills in } \\
\text { conducting learning variations was } 86.8 \% \text { and the percentage on the skills of explaining } \\
\text { lessons was } 78.6 \% \text {. Then, the percentage obtained on the indicator of skills in guiding small } \\
\text { group discussions was } 81.5 \% \text {, and the percentage on the skills of managing class was } 78 \% \text {. } \\
\text { Finally, the percentage on individual teaching skills obtained a percentage of } 72.6 \% \text {. It was } \\
\text { concluded that the teaching skills of teachers at SDN } 20 \text { Rupat was categorized as good, so } \\
\text { that the improvement of teachers' teaching skills also improve students'learning outcomes and } \\
\text { increased the learning success. }\end{array}$ \\
\hline
\end{tabular}

Accepted:

04 Desember 2021

$04^{\text {th }}$ December 2021

Published:

27 Desember 2021

$27^{\text {th }}$ December 2021
Keywords: teaching skills, the principal's role

Abstrak: Jenis penelitian berupa penelitian tindakan sekolah yang dilakukan oleh kepala sekolah menggunakan metode deskriptif kuantitatif yang menjelaskan dan menggambarkan hasil penelitian yang sesuai dengan fakta yang ditemukan. Tempat penelitian dilakukan di SDN 20 Rupat, dengan subjek penelitian adalah guru yang mengajar di SDN 20 Rupat. Hasil penelitian yang ditemukan adalah meningkatnya keterampilan guru dalam mengajar dan meningkatnya aktivitas guru ketika pembelajaran setelah beberapa tindakan yang dilakukan oleh kepala sekolah terhadap guru. Data hasil analisis observasi keterampilan mengajarar guru, rata-rata persentase keterampilan mengajar guru sebesar $79.4 \%$, pada indikator keterampilan membuka dan menutup pelajaran ditemukan data persentase sebesar $75.5 \%$, pada indikator keterampilan bertanya ditemukan data sebesar $82 \%$, pada indikator keterampilan memberikan penguatan terhadap siswa didapat persentase sebesar $80.5 \%$, pada indikator keterampilan mengadakan variasi pembelajaran didapat persentase $86.8 \%$, kemudian pada keterampilan menjelaskan pelajaran didapat persentase sebesar $78.6 \%$, selanjutnya pada indikator keterampilan membimbing diskusi kelompok kecil didapat persentase sebesar $81.5 \%$, selanjutnya pada keterampilan mengelola kelas didapat persentase sebesar $78 \%$, dan pada keterampilan mengajar individu didapat persentase sebesar $72.6 \%$. Dapat disimpulkan bahwa keterampilan mengajar guru di SDN 20 Rupat sudah dapat dikategorikan baik, sehingga dengan membaiknya keterampilan guru dalam mengajar baik pula hasil belajar siswa dan dapat meningkatkan keberhasilan pembelajaran.

Kata Kunci: keterampilan mengajar, peran kepala sekolah

\section{CITATION}

Rosmita. (2021). Peran Kepala Sekolah Dalam Meningkatkan Keterampilan Mengajar Guru Di SDN 20 Rupat. Primary: Jurnal Pendidikan Guru Sekolah Dasar, 10 (6), 1582-1588. DOI: http://dx.doi.org/10.33578/jpfkip.v10i6.8620. 


\section{PENDAHULUAN}

Pendidikan adalah suatu usaha yang dilakukan untuk memberikan pengetahuan bagi individu atau kelompok yang diberikan melalui pembelajaran formal maupun non formal dengan tujuan tidak lain yaitu untuk mencerdaskan bangsa. Sumber daya manusia merupakan kunci utama keberhasilan pembangunan, oleh sebab itu kualitas sumber daya manusia harus ditingkatkan sesuai dengan kemajuan ilmu pegetahuan dan teknologi serta perkembangan pembangunan nasional (Purwanto, 2002). Untuk meningkatkan kualitas sumber daya manusia maka upaya yang paling strategis adalah melalui pendidikan. Manusia membutuhkan pendidikan dalam kehidupannya, menurut Danim (2010) pendidikan merupakan usaha agar manusia dapat mengembangkan potensi dirinya melalui proses pembelajaran. Agar proses pendidikan di sekolah dapat berjalan dengan baik, dan mencapai tujuannya, maka diperlukan tenaga-tenaga pengajar yang memadai, berkualitas dan yang memiliki keterampilan mengajar yang tinggi (Uman, 2011). Dengan demikian sangatlah penting untuk memperhatikan keterampilan guru sehingga mampu mengembangkan metodemetode pembelajaran terbaru dan terus diupayakan secara maksimal agar mencapai tujuan yang diharapkan.

Dalam pengembangan keterampilan dan kemampuan guru dalam mengajar, kepala sekolah memiliki peran yang sangat penting dalam pengembangannya dikarenakan kepala sekolah sebagai seorang pemimpin yang sangat berpengaruh terhadap keterampilan guru. Kepala sekolah merupakan salah satu komponen pendidikan yang paling berperan penting dalam meningkatkan kualitas pendidikan (Ma'mur, 2012). Kepala sekolah adalah seorang tenaga fungsional guru, yang diberi tugas untuk memimpin suatu sekolah dimana diselenggarakannya proses belajar mengajar, atau tempat dimana terjadi interaksi guru dalam memberi pelajaran dan murid menerima pelajaran (Mulyasa, 2007). Sejalan dengan pendapat Chan dan Yuen (2014) menjelaskan bahwa peran kepala sekolah merupakan faktor yang signifikan dalam meningkatkan keterampilan mengajar guru, sehingga apabila peran kepala sekolah baik maka kemajuan sekolah akan tercapai.

Keterampilan mengajar guru sangat penting bagi hasil belajar siswa karena dengan adanya guru yang terampil yang mampu mengembangkan metode-metode pembelajaran terbaru dapat membuat siswa akan lebih aktif dan kreatif dalam proses pembelajaran. Namun kenyataannya, berdasarkan observasi sementara yang dilakukan kepala sekolah terhadap guru di SDN $20 \mathrm{X}$ menemukan bahwa masih banyak guru yang menggunakan metode lama dalam pembelajaran seperti ceramah dan membaca buku sehingga membuat siswa merasa bosan terhadap system pembelajaran yang seperti itu dari dulu. Melihat hal tersebut, kepala sekolah mengambil tindakan dengan meningkatkan keterampilan guru dalam mengajar, agar dapat menggunakan metode-metode pembelajaran terbaru yang diharapkan mampu untuk meningkatkan hasil belajar siswa dan membuat siswa lebih aktif dan kreatif dalam proses pembelajaran. Keberhasilan proses belajar mengajar merupakan hal yang diharapkan dalam pelaksanaan pendidikan di sekolah. Pencapaian hasil belajar yang baik diperoleh melalui proses pembelajaran yang berkualitas, yang melibatkan unsur-unsur pembelajaran dan mengoptimalkan potensi-potensi yang ada untuk mendukung terciptanya pencapaian nilai yang maksimal. Dalam hal ini, kepala sekolah perlu mengambil tindakan untuk mencapai tujuan pembelajaran (Purwanti, 2013). Beberapa tindakan yang dapat dilakukan oleh kepala sekolah yaitu dengan melakukan pembinaan, pengawasan atau supervisi, pelatihan, dan beberapa tindakan lainnya yang bertujuan meningkatkan mutu pendidikan. Tindakan yang diambil kepala sekolah yaitu dengan meningkatkan keterampilan mengajar guru. Keterampilan mengajar merupakan komptensi pedagogik yang cukup kompleks 
karena merupakan integrasi dari berbagai kompetensi guru secara utuh dan menyeluruh (Mulyasa, 2009). Oleh karena itu perlu adanya tindakan oleh kepala sekolah untuk meningkatkan keterampilan mengajar guru di SDN 20 Rupat Kabupaten Bengkalis.

\section{KAJIAN TEORI}

\section{Keterampilan mengajar}

Menurut Aunurrahman

Keterampilan mengajar adalah seperangkat kemampuan atau kecakapan. Keterampilan dapat diartikan sebagai suatu keahlian seseorang dalam melakukan suatu pekerjaan bidang tertentu. Bagi guru, keterampilan yang dimaksud adalah ahli melakukan tugas mengajar. Keterampilan merupakan kemampuan atau kompetensi yang dimiliki. Sedangkan keterampilan mengajar merupakan suatu karakteristik umum dari seseorang yang berhubungan dengan pengetahuan dan keterampilan yang diwujudkan melalui tindakan. Keterampilan mengajar pada dasarnya adalah berupa bentuk-bentuk perilaku yang bersifat khusus yang harus dimiliki oleh seorang guru sebagai cara dalam pengembangan untuk melaksanakan tugastugas mengajarnya secara terencana dan profesional. Keterampilan mengajar merupakan kemampuan yang dapat dipelajari serta diterapkan oleh setiap guru.

Dalam keterampilan mengajar guru terdiri dari 8 keterampilan mengajar yang sangat berperan dan menentukan kualitas pembelajaran, di antaranya keterampilan membuka dan menutup pelajaran, keterampilan bertanya, keterampilan memberikan penguatan, keterampilan mengadakan variasi, keterampilan menjelaskan, keterampilan membimbing diskusi kelompok kecil, keterampilan mengelola kelas dan keterampilan mengajar individu (Usman, 2007). Berdasarkan pendapat tersebut dapat disimpulkan bahwa seorang guru harus menguasai berbagai keterampilan mengajar untuk menciptakan pembelajaran yang efektif. Dengan menguasai keterampilan dasar mengajar, diharapkan juga guru dapat melaksanakan tugasnya sebagai guru yang profesional dalam mengembangkan potensi peserta didik agar tercapainya tujuan pendidikan.

\section{Peran kepala Sekolah}

Peranan kepala sekolah dalam rangka meningkatkan mutu pendidikan sangat penting karena dapat mempengaruhi berhasil dan tidaknya mutu pendidikan itu sendiri. Secara garis besar, ruang lingkup tugas kepala sekolah dapat diklasifikasikan ke dalam dua aspek pokok, yaitu pekerjaan di bidang administrasi sekolah dan pekerjaan yang berkenaan dengan pembinaan profesional kependidikan. Adapun peran kepala sekolah dalam meningkatkan mutu pendidikan, yang meliputi perannnya sebagai edukator, manajer, administrator, supervisor, leader, inovator, dan motivator (Rusmawati, 2013).

\section{METODE PENELITIAN}

Penelitian ini berupa penelitian tindakan sekolah yang dilakukan oleh kepala Sekolah. Penelitian ini memiliki tujuan untuk memperbaiki mutu pendidikan serta meningkatkan kemampuan guru dalam kegiatan pembelajaran (Imron, 2008). Penelitian dilakukan di SDN 20 Rupat, subjek dalam penelitian ini adalah guru yang mengajar di SDN 20 Rupat. Metode penelitian menggunakan deskriptif kuantitatif, metode bertujuan menjelaskan secara faktual apa yang terjadi dan ditemukan dalam penelitian tersebut. Penelitian ini terdiri dari 2 siklus, tahapan-tahapan yang dilalui dalam penelitian tindakan kelas yaitu perencanaan/persiapan tindakan, pelaksanaan tindakan, observasi, dan refleksi. Instrumen yang digunakan yaitu menggunakan lembar observasi untuk melihat keterampilan mengajar guru dan lembar observasi aktivitas guru pada saat kegiatan pembelajaran. 
Teknik Analisis Data

Teknik analisis data observasi aktivitas guru dan siswa dalam penelitian ini menggunakan rumus sebagai berikut:

$$
p=\frac{\mathrm{f}}{\mathrm{n}} \times 100 \%
$$

(Anas Sudijono, 2004)
Keterangan:

$$
\begin{array}{ll}
\mathrm{f} & =\text { Frekuensi yang sedang dicari } \\
& \text { persentasenya } \\
\mathrm{n} & =\text { Number of Cases (jumlah } \\
& \text { frekuensi/banyaknya individu) } \\
\mathrm{P} & =\text { Angka persentase } \\
100 \% & =\text { Bilangan Tetap }
\end{array}
$$

Tabel 1. Klasifikasi Pengukuran Persentase Hasil Observasi Aktivitas Guru dan Siswa

\begin{tabular}{ccc}
\hline No & Klasifikasi & Persentase $(\%)$ \\
\hline 1 & Baik & $67-100$ \\
2 & Cukup Baik & $34-66$ \\
3 & Kurang Baik & $0-33$ \\
\hline
\end{tabular}

(Arikunto, 2014).

\section{HASIL DAN PEMBAHASAN}

Keterampilan guru dalam mengajar adalah salah satu hal yang penting bagi tercapainya tujuan pembelajaran, karena keterampilan mengajar dapat mencakup hal- hal yang bersangkutan dengan peningkatan hasil belajar siswa. Berikut adalah data peningkatan persentase observasi keterampilan guru pada kegiatan pembelajaran di kelas:

Tabel 2. Data Analisis Observasi Keterampilan Guru

\begin{tabular}{cll}
\hline No. & \multicolumn{1}{c}{ Indikator } & Persentase \\
\hline $\mathbf{1 .}$ & keterampilan membuka dan menutup pelajaran & $75.5 \%$ \\
$\mathbf{2 .}$ & keterampilan bertanya & $82 \%$ \\
$\mathbf{3 .}$ & keterampilan memberikan penguatan & $80.5 \%$ \\
$\mathbf{4 .}$ & keterampilan mengadakan variasi & $86.8 \%$ \\
$\mathbf{5 .}$ & keterampilan menjelaskan & $78.6 \%$ \\
$\mathbf{6 .}$ & keterampilan membimbing diskusi kelompok kecil & $81.5 \%$ \\
$\mathbf{7 .}$ & keterampilan mengelola kelas & $78 \%$ \\
$\mathbf{8 .}$ & keterampilan mengajar individu & $72.6 \%$ \\
& \multicolumn{2}{r}{ Rata-rata } \\
\hline
\end{tabular}

Berdasarkan dari tabel di atas dapat dilihat data hasil analisis observasi keterampilan guru pada saat kegiatan pembelajaran ditemukan data peningkatannya dengan rata-rata persentase sebesar $79.4 \%$. berikut uraian persentase pada setiap indikator, pada indikator keterampilan membuka dan menutup pelajaran ditemukan data persentase sebesar $75.5 \%$, pada indikator keterampilan bertanya ditemukan data sebesar $82 \%$, pada indikator keterampilan memberikan penguatan terhadap siswa didapat persentase sebesar $80.5 \%$, pada indikator keterampilan mengadakan variasi pembelajaran didapat persentase $86.8 \%$, kemudian pada keterampilan menjelaskan pelajaran didapat persentase sebesar $78.6 \%$, selanjutnya pada indikator keterampilan membimbing diskusi kelompok kecil didapat persentase sebesar $81.5 \%$, selanjutnya pada keterampilan mengelola kelas didapat persentase sebesar $78 \%$, dan pada keterampilan mengajar individu didapat persentase sebesar $72.6 \%$. dapat dilihat dari uraian diatas bahwa keterampilan mengajar guru di SDN 20 Rupat sudah dapat dikategorikan baik, sehingga dengan membaiknya keterampilan guru dalam mengajar baik pula hasil belajar siswa dan dapat meningkatkan keberhasilan pembelajaran. 
Selain melakukan observasi keterampilan mengajar guru, peneliti juga melakukan observasi pada aktivitas guru dalam pembelajaran yang dilakukan selama empat kali pertemuan dalam dua siklus penelitian, berikut adalah data hasil observasi aktivitas guru pada saat kegiatan pembelajaran:

Tabel 3. Data analisis hasil observasi aktivitas guru

\begin{tabular}{llll}
\hline Siklus & Pertemuan & Persentase & kategori \\
\hline I & I & $56.3 \%$ & Cukup baik \\
& II & $62.1 \%$ & Cukup baik \\
II & III & $84 \%$ & Baik \\
& IV & $88.5 \%$ & Baik \\
\hline
\end{tabular}

Berdasarkan tabel diatas dapat dilihat data hasil analisis aktivitas guru selama proses pembelajaran yan dilakukan dalam dua siklus dan empat kali pertemuan. Pada siklus I pertemuan 1 data persentase aktivitas guru berjumlah $56.3 \%$ berada dalam kategori cukup baik, kemudian pada pertemuan 2 data persentase aktivitas guru meningkat menjadi $62.1 \%$ masih dalam kategori cukup baik, selanjutnya pada pertemuan 3 data aktivitas guru berjumlah $84 \%$ dengan kategori baik, dan pada pertemuan 4 data persentase aktivitas guru mengalami peningkatan yang signifikan dengan persentase berjumlah $88.5 \%$ pada kategori baik. Dapat dilihat bahwa upaya yang dilakukan kepala sekolah terhadap perbaikan pembelajaran juga berdampak baik terhadap aktivitas guru.

\section{Pembahasan}

Berdasarkan hasil penelitian dapat dilihat bahwa kepala sekolah telah memberikan sumbangsih yang baik dalam mengelola keterampilan mengajar guru dengan mengunakan tindakan yaitu, sebagai edukator, manager, administrator, supervisor, leader, inovator dan motivator. Setiap tindakan yang digunakan oleh kepala sekolah tersebut tergantung dengan kondisi situasi masingmasing guru. Dalam pelaksanaan pembinaan keterampilan mengajar guru, setiap guru diberikan materi dan pelatihan mana yang lebih sesuai dengan kemampuan yang dimiliki oleh guru untuk diterapkan dalam proses pembelajaran karena tidak semua guru memahami materi yang akan disampaikan dalam pelaksanaannya. Oleh karenanya peran kepala sekolah sangat menentukan ketercapaian hasil pembelajaran secara maksimal.

Hasil dalam penelitian ini terdiri dari meningkatnya keterampilan guru dalam mengajar dan meningkatnya aktivitas guru ketika pembelajaran. berikut data hasil analisis observasi keterampilan mengajarar guru, ratarata persentase keterampilan mengajar guru sebesar $79.4 \%$, pada indikator keterampilan membuka dan menutup pelajaran ditemukan data persentase sebesar $75.5 \%$, pada indikator keterampilan bertanya ditemukan data sebesar $82 \%$, pada indikator keterampilan memberikan penguatan terhadap siswa didapat persentase sebesar $80.5 \%$, pada indikator keterampilan mengadakan variasi pembelajaran didapat persentase $86.8 \%$, kemudian pada keterampilan menjelaskan pelajaran didapat persentase sebesar $78.6 \%$, selanjutnya pada indikator keterampilan membimbing diskusi kelompok kecil didapat persentase sebesar $81.5 \%$, selanjutnya pada keterampilan mengelola kelas didapat persentase sebesar $78 \%$, dan pada keterampilan mengajar individu didapat persentase sebesar $72.6 \%$. Dapat dilihat dari uraian diatas yag mendapatkan persentase tertinggi yaitu pada indikator keterampilan mengadakan variasi pembelajaran, variasi yang dimaksud adalah guru sudah mulai mampu menguasai berbagai macam metode pembelajaran terbaru dan mampu mengaplikasikannya ketika proses 
pembelajaran sehingga hal tersebut menjadi hal baru bagi siswa dan dapat membuat siswa akan lebih bersemangat lagi dalam belajar dengan adanya pembaharuan metode pembelajaran yang diberikan oleh guru. Dapat disimpulkan bahwa keterampilan mengajar guru di SDN 20 Rupat sudah dapat dikategorikan baik, sehingga dengan membaiknya keterampilan guru dalam mengajar baik pula hasil belajar siswa dan dapat meningkatkan keberhasilan pembelajaran.

Menurut Fanani (2013) menjelaskan bahwa peran kepala sekolah sangat penting terhadap keterampilan mengajar guru, karena kepala sekolah sebagai pimpinan dapat mengarahkan bawahannya untuk meningkatkan kualitas pembelajaran melalui pengawasan atau pembinaan yang baik dan memberikan kesempatan kepada guru untuk melatih kemampuan yang dimilikinya, sehingga guru dapat berkreasi dan mecoba halhal baru tentang sistem pembelajaran.

\section{KESIMPULAN}

Simpulan dalam penelitian ini adalah peran kepala sekolah dalam meningkatkan keterampilan mengajar guru dapat dikatakan berhasil dengan pemberian tindakan oleh kepala sekolah terhadap guru seperti pembinaan, pengawasan atau supervisi, pelatihan, dan beberapa tindakan lainnya yang bertujuan meningkatkan mutu pendidikan. Mengenai hal tersebut dapat ditarik kesimpulan bahwa keterampilan mengajar guru di SDN 20 Rupat sudah dapat dikategorikan baik, sehingga dengan membaiknya keterampilan guru dalam mengajar baik pula hasil belajar siswa dan dapat meningkatkan keberhasilan pembelajaran.

\section{DAFTAR PUSTAKA}

Aunurrahman. (2013). Belajar dan Pembelajaran. Bandung: Alfabeta

Anas, S. (2004). Pengantar Statistik Pendidikan. Jakarta: Raja Grafindo
Arikunto, S. (2014). Penelitian Tindakan Kelas. Jakarta: Rineka Cipta.

Chan, S., \& Yuen, M. (2014). Creativity beliefs, creative personality and creativity fostering practices of gifted education teachers and regular class teachers in Hong Kong. Thinking Skills and Creativity, 14, 109-118.

Danim S. (2010). Inovasi pendidikan dalam upaya meningkatkan profesionalisme tenaga kependidikan. Bandung: Pustaka Setia.

Fanani, Z. (2013). “Instrumen Kepemimpinan Pembelajaran Kepala Sekolah Dasar". Disertasi Doktor, tidak Ditebitkan, Universitas Negeri Yogyakarta.

Imron, A. (2008). Penelitian tindakan sekolah bagi pengawas dalam rangka peningkatan mutu pendidikan. Jurnal Tenaga Kependidikan Edisi Nomor 2 tahun 2008. Jakarta: Direktorat Tendik, Ditjen Mutendik, Depdiknas.

Mulyasa. (2007). Menjadi Kepala Sekolah Profesional. PT Remaja Rosdakarya. Bandung.

Ma'mur, A. (2012). Tips menjadi kepala sekolah profesional. Jogjakarta: diva press.

Purwanti, S. (2013). Peran Kepemimpinan Kepala Sekolah Dalam Eningkatkan Disiplin Kerja Guru Dan Pegawai Di Sma Bakti Sejahtera Kecamatan Kongbeng Kabupaten Kutai Timur. eJournal Administrasi Negara, 1(1), 210-224.

Purwanto, N. (2002). Administrasi dan Supervisi Pendidikan. Bandung: Remaja Rosda Karya

Rusmawati, V. (2013). Peran Kepemimpinan Kepala Sekolah Dalam Upaya Meningkatkan Disiplin Kerja Guru Pada SDN 018 Balikpapan. E-Journal Administrasi Negara. 1(2), 395-409.

Usman, U. (2011). Menjadi guru profesional jakarta: rosdakarya. UU RI No. 20 th. (2003). Tentang Sistem Pendidikan 


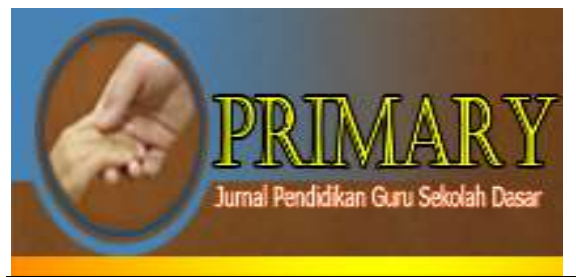

\section{PRIMARY: JURNAL PENDIDIKAN GURU SEKOLAH DASAR VOLUME 10 NOMOR 6 DESEMBER 2021 \\ ISSN : 2303-1514 | E-ISSN : 2598-5949 \\ DOI : http://dx.doi.org/10.33578/jpfkip.v10i6.8620 https://primary.ejournal.unri.ac.id/index.php/JPFKIP}

Nasional dan penjelasannya.

Bandung: Citra Umbara.

Usman, U. (2007). Upaya Optimalisasi

Kegiatan Belajar Mengajar. Bandung :

PT Remaja Rosdakarya. 